\title{
FSHD myoblasts fail to downregulate intermediate filament protein vimentin during myogenic differentiation
}

\author{
P. V. Dmitriev, A. L. Barat, E. Cochet, V. V. Ogryzko, D. Laoudj-Chenivesse', \\ M. Lipinski, Y. S. Vassetzky
}

UMR8126, Univ. Paris-Sud 11, CNRS, Institute Gustave Roussy 94805 Villejuif, France

${ }^{1}$ Inserm U1046, Universite Montpellier 1, Universite Montpellier 2 371 Avenue du Doyen G. Giraud, Montpellier, France, 34295

dmitriev@igr.fr

\begin{abstract}
Facioscapulohumeral muscular dystrophy (FSHD) is an autosomal dominant hereditary neuromuscular disorder. The clinical features of FSHD include weakness of the facial and shoulder girdle muscles followed by wasting of skeletal muscles of the pelvic girdle and lower extremities. Although FSHD myoblasts grown in vitro can be induced to differentiate into myotubes by serum starvation, the resulting FSHD myotubes have been shown previously to be morphologically abnormal. Aim. In order to find the cause of morphological anomalies of FSHD myotubes we compared in vitro myogenic differentiation of normal and FSHD myoblasts at the protein level. Methods. We induced myogenic differentiation of normal and FSHD myoblasts by serum starvation. We then compared protein extracts from proliferating myoblasts and differentiated myotubes using SDS-PAGE followed by mass spectrometry identification of differentially expressed proteins. Results. We demonstrated that the expression of vimentin was elevated at the protein and $m R N A$ levels in FSHD myotubes as compared to normal myotubes. Conclusions. We demonstrate for the first time that in contrast to normal myoblasts, FSHD myoblasts fail to downregulate vimentin after induction of in vitro myogenic differentiation. We suggest that vimentin could be an easily detectable marker of FSHD myotubes.
\end{abstract}

Keywords: FSHD, vimentin, myogenic differentiation, proteomics.

Introduction. FSHD is a dominant neuromuscular disease linked to chromosomal rearrangement within the subtelomeric region of chromosome $4 q(4 q 35)$ with a prevalence of 7 in 100000 characterized by weakness and wasting of the facial muscles, the shoulder and pelvic girdle muscles and the muscles of lower extremities (for review see [1]). The disorder is genetically linked to a deletion of an integral number of tandemly arrayed D4Z4 repeat units [2]. The D4Z4 repeats and neighbouring regions of the $4 \mathrm{q} 35$ locus are enriched in various regulatory elements [3-5]. Transcriptional profiling of muscle biopsies of FSHD patients and in vitro

(C) Institute of Molecular Biology and Genetics, NAS of Ukraine, 2011 cultured FSHD myoblasts revealed a defect in myogenic differentiation program $[6,7]$ and deregulation of genes related to oxidative stress $[8,9]$. Deregulation of proteins involved in oxidative stress and mitochondrial metabolism was also demonstrated in muscle biopsies of FSHD patients by a proteomic approach $[6,8]$.

It is of note, that transcriptome and proteome profiling of muscle biopsies or crude, non-purified myoblast cultures can be biased by the presence of contaminating non-muscle cells. This problem is especially pronounced in case of muscular dystrophies where infiltration of muscle tissue by inflammatory, fat or connective tissue cells is a well-known phenomenon [10]. However, up to now proteomic analysis has not been done on pu- 
re FSHD myoblasts sorted using an appropriate surface marker e. g. CD56 (NCAM) that is expressed in myoblasts but not in adipocytes or fibroblasts.

Here we report the first proteomics analysis of CD56+ FSHD myoblasts. We found that in contrast to myoblasts isolated from normal individuals, FSHD myoblasts fail to downregulate vimentin after induction of in vitro myogenic differentiation. The increased expression of intermediate filament protein vimentin might contribute to abnormal morphology of FSHD myotubes observed previously [11].

Materials and methods. Cell culture. Primary CD56+ myoblasts were isolated from normal subjects and FSHD patients as described [11]. Proliferating myoblasts were cultivated in proliferating medium (DMEM \# D6546 («Sigma», USA), Glutamine $4 \mathrm{mM}$, Gentamycin $50 \mu \mathrm{g} / \mathrm{ml}, 10 \%$ FCS) at $40-50 \%$ confluency. To induce myogenic differentiation via serum starvation, proliferating myoblasts were placed for 3 days in differentiation medium (DMEM \# D6546 («Sigma»), Glutamine $4 \mathrm{mM}$, Gentamycin $50 \mu \mathrm{g} / \mathrm{ml}, 2 \%$ FCS) at confluency $70-80 \%$.

Protein extraction and gel-electrophoresis. Cells were washed by $1 \times$ PBS then lyzed directly on plates using RIPA buffer [12]. Protein extracts were separated on $10 \%$ SDS-PAGE (10 $\mu$ g per lane) which was then stained by Coomassie Blue.

Mass-spectrometry analysis. A band of interest was excised from Coomassie stained gel and processed as described [13]. The peptide mixtures obtained from tryptic digestion of the band were analyzed with a nanoHPLC (Agilent Technologies 1200) directly coupled to an ion-trap mass spectrometer (Bruker 6300 series) equipped with a nano-electrospray source. The separation gradient from $3 \%$ to $50 \%$ acetonitrile was applied for $30 \mathrm{~min}$, the fragmentation voltage was $1.3 \mathrm{~V}$. The protein identification was performed with Spectrum Mill software package. For the confirmation and quantification of vimentin-specific peptides with $\mathrm{m} / \mathrm{z}$ ratios 544.7 (QDVDNASLAR); 635.8 (LGDLYEEEMR); and 662 (EEAENTLQSFR) the ion trap was set in a MRM mode as described [13]. The analysis of the MRM data was performed with the DataAnalysis for the 6300 Series Ion Trap LC/MS Version 3.4 software package.

$q R T-P C R$. Cells were lysed directly on plates using Trizol («Invitrogen», USA) followed by RNA isolation according to manufacturer's protocol. $400 \mathrm{ng}$ of total RNA was reverse-transcribed using high-capacity cDNA Archive kit («Applied Biosystems» (AB) \# 4322171). cDNA equivalent to $200 \mathrm{ng}$ of total RNA was mixed with $2 \times$ TaqMan Gene Expression master mix (AB \# 4369016) and $100 \mu \mathrm{l}$ of amplification mixture were injected per port into Custom TLDA (TaqMan Low Density Array, AB). PCR amplification and fluorescence reads were performed on ABI Prism 7900HT.

Results and discussion. Total protein extracts prepared from proliferating myoblasts and differentiated myotubes originating from two healthy subjects and two FSHD patients were separated on SDS-PAGE. Coomassie Blue staining revealed that the band $a$, but not the band $b$ used as a control, was less intense in normal differentiated myotubes compared to proliferating myoblasts, but had the same intensity in myoblasts and myotubes from FSHD patients (Figure, $A$ ). We then used mass spectrometry to identify proteins that might constitute the band of interest and found that the most likely candidate is vimentin (42 peptides identified covering $72 \%$ of amino acid sequence of vimentin). We then measured the quantity of several vimentinspecific tryptic peptides and found that they were less abundant in normal myotubes compared to myoblasts (Figure, $B$ ). However, the amount of vimentin-specific peptides was not reduced in FSHD myotubes compared to myoblasts. We then confirmed this result by measuring the level of vimentin mRNA using qRT-PCR (Figure, $C$ ). We conclude that FSHD myoblasts are unable to repress vimentin production during in vitro myogenic differentiation.

Three filamentous networks constitute the cytoskeleton in higher eukaryotes: microtubules, actin microfilaments and intermediate filaments (for review see [14]). Intermediate filament protein vimentin is expressed during muscle development or regeneration but not in mature myofibers, where desmin becomes the major intermediate filament protein $[15,16]$.

Normal human myoblasts cultured in vitro express both vimentin and desmin. Serum starvation-induced myogenic differentiation leads to vimentin repression and desmin induction [17]. To rule out the possibility that the failure of FSHD myoblasts to downregulate vimentin is simply due to their inability to differentiate, we examined the expression of several myogenic mar- 


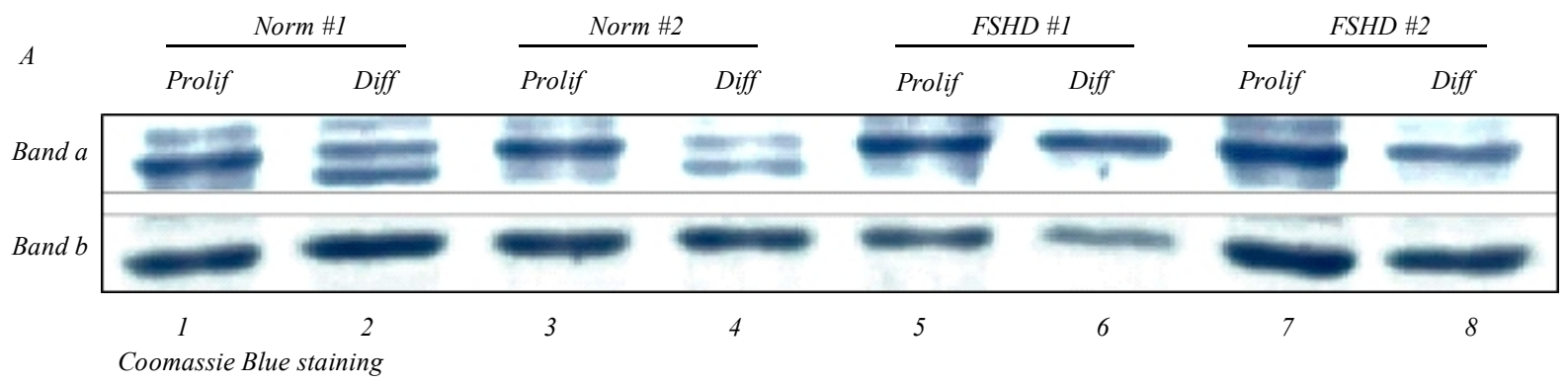

$B$

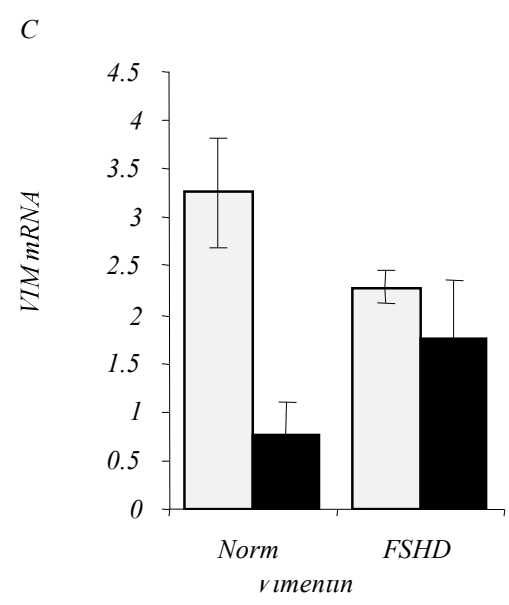

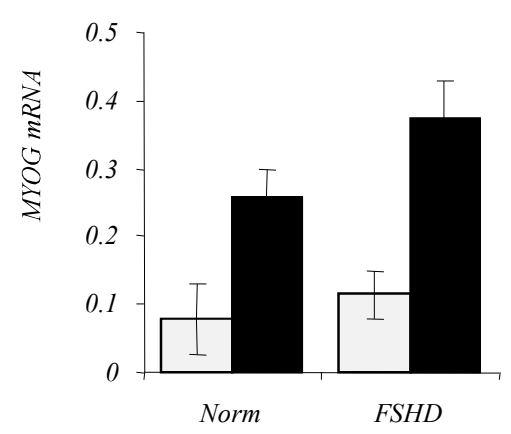

Myogenin

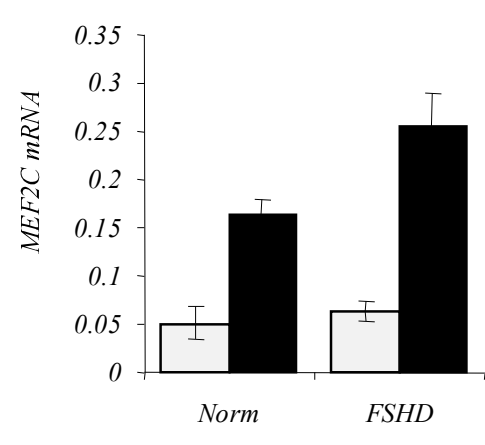

$M E F 2 C$

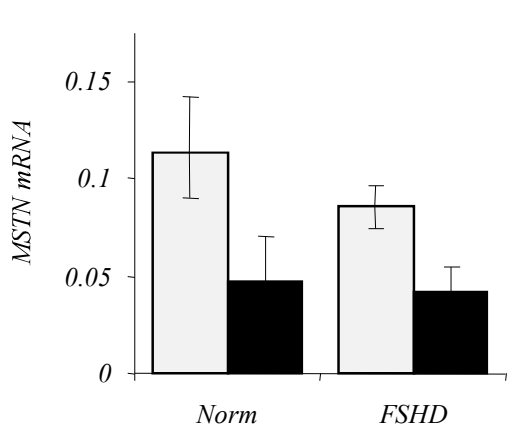

Myostatin

$A$ - Coomassie Blue stained SDS-PAGE was used to analyze total protein extracts from normal and FSHD proliferating myoblasts (Prolif) and differentiated myotubes (Diff). Vimentin was identified via mass spectrometry as the protein constituting the band of interest (band $a$ ); $B$ - the quantity of 3 vimentin-specific peptides was measured in the band $a$ using mass spectrometry. The quantity of each peptide in lanes 2-8 was normalized to its quantity in the lane 1 . The average of three vimentin-specific peptides is shown; $C$-the level of vimentin mRNA was measured using qRT-PCR (TaqMan) in 5 normal and FSHD myoblasts and myotubes. Vimentin mRNA level was normalized to GAPDH mRNA; $D$ - the expression of myogenesis markers MYOG, MEF2C and MSTN was measured using qRT-PCR in 5 normal and FSHD myoblasts and myotubes. Grey columns - proliferating myoblasts, black-differentiated myotubes. Expression levels were normalized to GAPDH mRNA. Error bars represent S. E. M., ${ }^{*} \mathrm{p}-$ value $<0.05$; **p - value $<0.01$ (Student's $t$-test)

kers in differentiated FSHD myotubes. We found that in both normal and FSHD myotubes the expression of myogenesis-related transcription factors MEF2C and Myogenin (MYOG) was upregulated, while the gene of myogenesis inhibitor Myostatin (MSTN) was repressed
(Figure, $D$ ) indicating that serum starvation induces myogenic differentiation program in FSHD myoblasts.

The elevated level of vimentin in FSHD myotubes might be explained by incomplete repression of vimentin gene promoter in these cells. The promoter of hu- 
man vimentin gene contains binding sites for $\mathrm{NF}-\mathrm{\kappa B}$, ZBP-89 and other transcription factors [18]. ZBP-89 represses while NF- $\mathrm{kB}$ and other factors activate vimentin promoter $[19,20]$. Normal and FSHD myotubes expressed ZBP-89 at similar level (data not shown). Therefore, vimentin overexpression in FSHD myotubes is not caused by insufficient expression of its repressor ZBP-89.

Conversely, vimentin gene overexpression in FSHD myotubes might be linked to NF- $\mathrm{KB}$ activity. As NF- $\mathrm{KB}$ activity was shown to be higher in FSHD [21], we speculate that vimentin overexpression in FSHD myotubes might be due to constitutive activation of NF- $\mathrm{KB}$ pathway in FSHD.

The defect in cytoskeleton organization of FSHD myotubes was observed previously. In contrast to normal myotubes that form regular myofiber structure, FSHD myotubes form either abnormally thin myofibers or chaotically connected myofibers (atrophic or disorganized phenotype respectively) [11]. Vimentin is dispensable for myotube morphology of chicken myoblasts in vitro [22], anomalies in skeletal muscles have not been noted in transgenic mice with disrupted vimentin intermediate filaments [23] and vimentin gene overexpressing transgenic mice [24].

Therefore, it is unlikely that vimentin gene expression could cause myotube disorganization in FSHD. However, vimentin overexpression is an indicator of damaged and regenerating muscle [16]. Vimentin staining was suggested as a useful marker for regenerating fibers in muscle biopsies from patients with neuromuscular disorders [25]. We suggest that the overproduction of vimentin, a very abundant intermediate filament protein, could be used as a marker of FSHD myotubes in vitro.

Acknowledgements. The research has been supported by grants from the Association Francaise contre les Myopathies (AFM).

$\mathrm{AB}$ was a recipient of the IRC-SET-Marie Curie International Mobility Fellowships in Science Engineering and Technology. VO was supported by grants from «La Ligue Contre le Cancer» (9ADO1217/ 1B1-BIOCE), the «Institut National du Cancer» (247343/1B1-BIOCE) and Centre National de la Recherche Scientifique (CNRS-INCA-MSHE FrancePoland \# 3037987).
П. В. Дмитрієв, А. Л. Барат, С. Коче, В. В. Огризко, Д. Лауж-Шенівес, М. Ліпінський, С. С. Васеиький

Міобласты хворих на міодистрофію Ландузі-Дежеріна не спроможні репресувати ген віментину за перебігу м'язового диференціювання

Резюме

Плечо-лопатково-лицева м'язова дистрофія (міодистрофія Ландузі-Дежсеріна) є аутосомним домінантно-успадковуваним нейром'язовим захворюванням. До клінічних ознак даного типу м'язовоі дистрофії належать слабкіть і атрофія лицевих м'язів плечового пояса, до яких на пізніших стадіях захворювання додаються м'язи пояса нижніх кінцівок. Незважаючи на те, що міобласти, виділені із хворих на міодистрофію Ландузі-Дежеріна, здатні до диференціювання in vitro, міотрубки, які виникли з них, мають низку морфологічних аномалій. Мета. Мета даної роботи полягає в пошуку причини морфологічних аномалій міотрубок пацієнтів 3 міодистрофією Ландузі-Дежеріна. Методи. Із використанням ростового середовища з низьким вмістом сироватки ми індукували м'язове диференціювання нормальних міобластів і міобластів пацієнтів з міодистрофією Ландузі-Дежеріна та проаналізували білковий склад міотрубок, які виникли з них, методом СДС-ПААГ з наступною ідентифікацією білків методом масс-спектрометрії. Результати. В представленій роботі вперше показано, що в міотрубках пацієнтів з міодистрофією Ландузі-Дежеріна підвищена експресія гена віментину. Висновки. Віментин можна застосовувати як ген - маркер міотрубок хворих на міодистрофію Ландузі-Дежеріна.

Ключові слова: міодистрофія Ландузі-Дежеріна, віментин, м'язове диференціювання, протеоміка.

П. В. Дмитриев, А. Л. Барат, Е. Кочэ, В. В. Огрызко, Д. Лауж-Шенивес, М. Липинский, Е. С. Васеикий

Миобласты больных миодистрофией Ландузи-Дежерина не способны к репрессии гена виментина в ходе мышечной дифференцировки

Резюме

Лице-лопаточно-бедренная мышечная дистрофия (миодистрофия Ландузи-Дежерина) является аутосомным доминантно-наследуемым нейромышечным заболеванием. Клиническая картина данного типа мышечной дистрофии включает слабость и атрофию лицевых мыши и мыши плечевого пояса, к которым на более поздних стадиях заболевания добавляются мышиы пояса нижних конечностей. Несмотря на то, что миобласты, выделенные из больных миодистрофией Ландузи-Дежерина, способны к дифференцировке in vitro, возникающие из них миотрубки имеют ряд морфологических аномалий. Цель. Целью данной работы является поиск причины морфологических аномалий миотрубок пациентов с миодистрофией Ландузи-Дежерина. Методы. Используя ростовую среду с низким содержанием сыворотки, мы индуцировали мышечную дифференцировку нормальных миобластов и миобластов пациентов с миодистрофией Ландузи-Дежерина и проанализировали белковый состав возникших из них миотрубок методом СДС-ПААГ с последующей идентификачией белков методом масс-спектрометрии. Результаты. В данной работе впервые показано, что в миотрубках пациентов с миодистрофией Ландузи-Дежерина увеличена экспрессия гена виментина. Выводы. Виментин может быть использован в качестве гена -маркера миотрубок больных миодистрофией Ландузи-Дежерина. 
Ключевые слова: миодистрофия Ландузи-Дежерина, виментин, мымечная дифференцировка, протеомика.

\section{REFERENCES}

1. Dmitriev P., Lipinski M., Vassetzky Y. S. Pearls in the junk: dissecting the molecular pathogenesis of facioscapulohumeral muscular dystrophy // Neuromuscul. Disord.-2009.-19, N 1.P. 17-20.

2. van Deutekom J. C., Wijmenga C., van Tienhoven E. A., Gruter A. M., Hewitt J. E., Padberg G. W., van Ommen G. J., Hofker M. $H$., Frants $R$. R. FSHD associated DNA rearrangements are due to deletions of integral copies of a $3.2 \mathrm{~kb}$ tandemly repeated unit // Hum. Mol. Genet.-1993.-2, N 12.-P. 2037-2042.

3. Petrov A., Laoudj D., Vasetskii E. Genetics and epigenetics of facio-scapulohumeral progressive (Landouzy-Dejerine) muscular dystrophy // Genetika.-2003.-39, N 2.-P. 202-206.

4. Petrov A., Pirozhkova I., Carnac G., Laoudj D., Lipinski M., Vassetzky Y. S. Chromatin loop domain organization within the $4 \mathrm{q} 35$ locus in facioscapulohumeral dystrophy patients versus normal human myoblasts // Proc. Natl. Acad. Sci. USA.-2006.103, N 18.-P. 6982-6987.

5. Petrov A., Allinne J., Pirozhkova I., Laoudj D., Lipinski M., Vassetzky Y. S. A nuclear matrix attachment site in the 4q35 locus has an enhancer-blocking activity in vivo: implications for the facio-scapulo-humeral dystrophy // Genome Res.-2008.-18, N 1.-P. 39-45.

6. Celegato B., Capitanio D., Pescatori M., Romualdi C., Pacchioni B., Cagnin S., Vigano A., Colantoni L., Begum S., Ricci E., Wait R., Lanfranchi G., Gelfi C. Parallel protein and transcript profiles of FSHD patient muscles correlate to the D4Z4 arrangement and reveal a common impairment of slow to fast fibre differentiation and a general deregulation of MyoD-dependent genes // Proteomics.-2006.-6, N 19.-P. 5303-5321.

7. Winokur S. T., Chen Y. W., Masny P. S., Martin J. H., Ehmsen J. T., Tapscott S. J., van der Maarel S. M., Hayashi Y., Flanigan K. $M$. Expression profiling of FSHD muscle supports a defect in specific stages of myogenic differentiation // Hum. Mol. Genet.-2003.-12, N 22.-P. 2895-2907.

8. Laoudj-Chenivesse D., Carnac G., Bisbal C., Hugon G., Bouillot S., Desnuelle C., Vassetzky Y., Fernandez A. Increased levels of adenine nucleotide translocator 1 protein and response to oxidative stress are early events in facioscapulohumeral muscular dystrophy muscle // J. Mol. Med. (Berl).-2005.-83, N 3.P. 216-224.

9. Winokur S. T., Barrett K., Martin J. H., Forrester J. R., Simon M., Tawil R., Chung S. A., Masny P. S., Figlewicz D. A. Facioscapulohumeral muscular dystrophy (FSHD) myoblasts demonstrate increased susceptibility to oxidative stress // Neuromuscul. Disord.-2003.-13, N 4.-P. 322-333.

10. Davies K. E., Nowak K. J. Molecular mechanisms of muscular dystrophies: old and new players // Nat. Rev. Mol. Cell Biol.2006.-7, N 10.-P. 762-773.

11. Barro M., Carnac G., Flavier S., Mercier J., Vassetzky Y., Laoudj-Chenivesse D. Myoblasts from affected and non-affected FSHD muscles exhibit morphological differentiation defects // J. Cell Mol. Med.-2010.-14, N 1-2.-P. 275-289.

12. Yu J., de Belle I., Liang H., Adamson E. D. Coactivating factors p300 and CBP are transcriptionally crossregulated by Egr1 in prostate cells, leading to divergent responses // Mol. Cell.2004.-15, N 1.-P. 83-94.

13. Saade E., Mechold U., Kulyyassov A., Vertut D., Lipinski M., Ogryzko $V$. Analysis of interaction partners of $\mathrm{H} 4$ histone by a new proteomics approach // Proteomics.-2009.-9, N 21.P. 4934-4943.

14. Duprey P., Paulin D. What can be learned from intermediate filament gene regulation in the mouse embryo // Int. J. Dev. Biol.-1995.-39, N 3.-P. 443-457.

15. Sarnat H. B. Vimentin and desmin in maturing skeletal muscle and developmental myopathies // Neurology.-1992.-42, N 8.P. 1616-1624.

16. Gallanti A., Prelle A., Moggio M., Ciscato P., Checcarelli N., Sciacco M., Comini A., Scarlato G. Desmin and vimentin as markers of regeneration in muscle diseases // Acta Neuropathol.-1992.-85, N 1.-P. 88-92.

17. van der Ven P. F., Schaart G., Jap P. H., Sengers R. C., Stadhouders $A$. M., Ramaekers $F$. C. Differentiation of human skeletal muscle cells in culture: maturation as indicated by titin and desmin striation // Cell Tissue Res.-1992.-270, N 1.-P. 189198.

18. Salmon M., Zehner Z. E. The transcriptional repressor ZBP-89 and the lack of Sp1/Sp3, c-Jun and Stat3 are important for the down-regulation of the vimentin gene during $\mathrm{C} 2 \mathrm{C} 12$ myogenesis // Differentiation.-2009.-77, N 5.-P. 492-504.

19. Wieczorek E., Lin Z., Perkins E. B., Law D. J., Merchant J. L., Zehner Z. E. The zinc finger repressor, ZBP-89, binds to the silencer element of the human vimentin gene and complexes with the transcriptional activator, Sp1 // J. Biol. Chem.-2000.275, N 17.-P. 12879-12888.

20. Salvetti A., Lilienbaum A., Li Z., Paulin D., Gazzolo L. Identification of a negative element in the human vimentin promoter: modulation by the human T-cell leukemia virus type I Tax protein // Mol. Cell Biol.-1993.-13, N 1.-P. 89-97.

21. Macaione V., Aguennouz M., Rodolico C., Mazzeo A., Patti A., Cannistraci E., Colantone L., Di Giorgio R. M., De Luca G., Vita $G$. RAGE-NF-kappaB pathway activation in response to oxidative stress in facioscapulohumeral muscular dystrophy // Acta Neurol. Scand.-2007.-115, N 2.-P. 115-121.

22. Schultheiss T., Lin Z. X., Ishikawa H., Zamir I., Stoeckert C. J., Holtzer $H$. Desmin/vimentin intermediate filaments are dispensable for many aspects of myogenesis // J. Cell Biol.-1991.114, N 5.-P. 953-966.

23. Pieper F. R., Raats J. M., Schaart G., Dunia I., van der Kemp A., Benedetti E. L., Ramaekers F. C., Bloemendal H. Disruption of vimentin intermediate filaments in transgenic mice by expression of a dominant negative mutant desmin subunit // Eur. J. Cell Biol.-1995.-68, N 4.-P. 355-368.

24. Capetanaki Y., Starnes S., Smith $S$. Expression of the chicken vimentin gene in transgenic mice: efficient assembly of the avian protein into the cytoskeleton // Proc. Natl. Acad. Sci. USA.1989.-86, N 13.-P. 4882-4886.

25. Bornemann A., Schmalbruch H. Desmin and vimentin in regenerating muscles // Muscle Nerve.-1992.-15, N 1.-P. 14-20.

UDC 616.7

Received 20.07.11 